\title{
ON THE DIALECTOLOGICAL LANDSCAPE OF ARABIC AMONG THE JEWISH COMMUNITY OF BEIRUT
}

\author{
AHARON GEVA-KLEINBERGER \\ Department of Arabic Language and Literature \\ University of Haifa, Israel \\ e-mail: ageva@univ.haifa.ac.il
}

The research reported here is based on dialectological fieldwork among Lebanese Jews from 2006 to 2015. In the 20th century most Jews of Beirut lived in the Jewish Wādi 'Abu Žmīl quarter, an area measuring 300 metres by one kilometre. Very few families lived in other parts of the city. The Beirut community consisted of Jews originally Lebanese, Syrian Jews from Aleppo and Damascus, numerous Ashkenazi Jews, Jews originally Maghrebi, some Kurdish Jews, Jews from Turkey and Greece, especially Salonika, and Sephardi Jews originally from Andalusia who reached Beirut after their expulsion from Spain in 1492. The Beirut Jews' dialect differed from that of the Sidon Jews, but in many respects also from the dialects of the Beirut Arabs, lacking highly typical phenomena such as the Imāla. Like diverse other Modern Judeo-Arabic dialects, this one embraces the vast array of vocabulary used in Jewish life. At its height Beirut's Jewish community numbered several thousands, but over time it dwindled and disappeared - together with its dialect. Most of its speakers left, many of them for Israel, where the fieldwork was undertaken.

Key words: Arabic dialectology, Judeo-Arabic, Modern Judeo-Arabic, fieldwork, language anthropology, language obsolescence, Lebanon, Jews, Beirut, Sidon, Jewish communities.

\section{Fieldwork and Linguistic Informants}

This study is based on fieldwork among nine Beiruti Jews [yahüd Bayārte ${ }^{1}$ ] undertaken between 2006 and 2015. In 2006 two of my students, Yael Kaufmann and Elite Hayya, recorded Sofi Yael Srūr and Rachel Lazar. Elite was also present at my own recording of Yehudit Pardés in 2006. I took the other six recordings in 2015 at

${ }^{1}$ In the same morphological pattern the Sidonese Jews were called yahūd Sayādne (compare the nisbe form of the Moslems of Sidon who called themselves Saydawiyye); on additional nisbe-forms in Baskinta (Lebanon), see Farida Abu-Haidar (1979, p. 64). 
Karmiel, Haifa, Ramat-Gan, Bat-Yam, Holon, and Jerusalem. All the informants were born in Beirut between the 1920s and the 1950s. Their names, with the abbreviations used here and the years of recording, are: Sofi Ya ${ }^{\uparrow} \bar{e}$ Srūr (SYN, 2006), Rachel Lazar (RL, 2006), Yehudít Pardés ${ }^{2}$ (YP, 2006), Ya'akóv ${ }^{3}$ (Jacques) Kamhin (YK, 2015), ${ }^{\complement}$ Abdo ('Ovádya) ${ }^{\complement} A b b u ̄ d^{4}$ (AA, 2015), Allegra ${ }^{\complement} A b b u \bar{d}{ }^{5}$ (AAA, 2015), Eli Zaytūni ${ }^{6}$ (ElZ, 2015), Mordechaï Zaytūni ${ }^{7}$ (MrZ, 2015), Moshe Za $a^{\varsigma}$ afrāni $^{8}$ (MsZ, 2015).

\section{Essential Historical Background on the Jewish Community in Beirut}

In the mid-20th century there were about 5000 Jews in Beirut. This was the largest Jewish community in Lebanon; the second largest was that in Sidon. ${ }^{9}$ Most of the Jews came to the city from the Druze village of Dér el ${ }^{2}$ Amar in $1860,{ }^{10}$ consequent to the brutal civil war between the Druze and the Christians. Yet some informants said that even before this migration wave there was an ancient Jewish core in Beirut consisting of three almost mythological families whose names rhymed: Dāna, Hanna, and Manna. ${ }^{11}$ They lived in the vicinity of the Upholsterers Market (SüpliMnažždinn) and the Sirsō $\bar{o}^{?}$ Market $\left(\operatorname{Su}^{\urcorner} \operatorname{Sirs}_{\bar{o}}\right)$. According to ElZ, at that stage the Jews were influenced linguistically by their Sunnite neighbours.

In the 20th century most Jews lived in the Jewish Quarter of Wādi ' $A b u$ Žminl, an area measuring 300 metres by one kilometre. Very few families lived in other parts of the city. The Beirut community consisted of Jews who were originally Lebanese, ${ }^{12}$ Syrian Jews from Aleppo and Damascus, numerous Ashkenazi Jews ( $\check{S} a k \bar{a} n z e \sim S a-$ $k \bar{a} n z ̌ e)$, Jews from Maghrebi (Maḡārbbe $\left.e^{13}\right)$, some Kurdish Jews (krād), Jews from

${ }^{2}$ Born Widād Srūr on 18 August 1927.

${ }^{3}$ Born in July 1956.

${ }^{4}$ Born on 5 February 1939.

${ }^{5}$ Born 'Allégra 'Argálži in 1947.

${ }^{6}$ Born on 2 May 1953. The original name of the Zaytūni family was Zaytūne (زيتونه).

${ }^{7}$ Born in August 1932.

${ }^{8}$ Born on 31 August 1955 .

${ }^{9}$ Schulze (2001, p. 20): "The Community of Saida had been embellished by mainly Maghrebi Jews from the Shouf who brought with them rural traditions which they implanted onto the terrain around this predominantly Sunni city." Today, there are officially about fifty Jews in Beirut. The Magen Avraham synagogue was lately refurbished. See more in Qabbāni (2014).

${ }^{10}$ yahūdi Dirāni [A Jew from Dēr el'Amar] pl. yahūd Dyārne. The Kohēn-Hallāle family was one of the prominent Jewish families from Dēr elAmar.

${ }^{11}$ There is connection also to the name elMenn, or elMenn synagogue or elMenn-Alley [Zarūbat elMenn, YK, 1]. See also Levi (2012, p. 174). This might be the source of the well-known saying "bēn Hanna w Manna d $\bar{a}^{\varsigma} a t$ lhāna" [= between Hanna and Manna we lost our beard]; it concerns two women, the wives of an old man. The younger plucked the grey hairs from his beard to make him look young, the older the black hairs to make him look old. In the end he lost his entire beard, symbolising loss of respect.

${ }_{12}$ They are called by some informants Musta'ribin, literally 'Arabised'.

${ }^{13}$ E.g. the family of ${ }^{?}$ Abrahäm Larīdo, originally from Tetwan. 
Turkey ${ }^{14}$ and Greece, especially Salonika, ${ }^{15}$ and Sephardi Jews originally from Andalusia who reached Beirut after their expulsion from Spain in 1492 (this group was collectively called Spanyoliyye ${ }^{16}$ ). There were also some Jewish families of Italian origin. ${ }^{17}$ Thus, the linguistic landscape of the Jewish community was heterogeneous, as every subcommunity spoke its own mother tongue at home and at the synagogue. The Ashkenazim spoke Yiddish, the Spanyoliyye Ladino, and the old Jews from Syria their original dialects of Aleppo or Damascus. However, whenever the diverse groups of Jews intermingled, they spoke an Arabic dialect characteristic of the Beirut Jewish community; even the young generation of Syrian Jews abandoned their parents' dialects for this dialect (hence JBD). Hearing it spoken, Christians, Moslems, and Druze often diagnosed it - mistakenly - as a "Syrian dialect" and not as Lebanese. ElZ believes that originally the Jewish dialect of Beirut was influenced by the Sunni dialects of the city, as was the ancient core of the three Jewish families that once lived in a Sunni environment.

Most of the Jews of Beirut spoke fluent French, and many also knew English. Both languages were taught at schools.

An amazing fact is that Hebrew was taught legally and officially in Lebanon. This is perhaps the only Arab country in the mid-20th century where Modern Hebrew, Ivrit, was taught $;{ }^{18}$ together with this there was a semi-open permit to conduct activities of Jewish organisations such as Maccabi. As a result, most of the Lebanese Jewish newcomers to Israel easily integrated linguistically.

The Jews of Beirut used the Hebrew word goyyim (sing. gōy, Heb. ג גוי < only for the Moslems, while the word 'arelìm [sing. ' ${ }^{\wedge}$ areel, Heb. ערלים] was used to denote Christians.

\section{Dialectal Remarks}

\subsection{Phonology}

The Beiruti informants show almost unanimous use of the ancient ${ }^{*} q$ as a glottal stop $(>$ '). Only very rarely did I find in the texts some exceptional deviations, where a $k$ was the allophone.

No interdentals are reflected in the speech of the various informants. As in other Lebanese dialects sometimes the Classical Arabic $ث$ turns into its voiceless dental sibilant $s$, e.g. hawādis (< hawādit 'events') (AA, 8).

Thus is the dialect of the Jews of Beirut urban in nature.

${ }^{14}$ E.g. the ${ }^{?} A s ̌ k e n a \bar{z} i$ and Baxxār families.

${ }_{16}^{15}$ E.g. the Sfinzi and 'Úški families.

${ }^{16}$ YK mentioned two families that spoke Ladino at home: Kário and Šalhōn.

${ }^{17}$ E.g. Galānte and Tèlio.

${ }^{18}$ The most prominent teacher of Modern Hebrew was Moshe Qamheen (Mošé 'Amhīn) who died in New Mexico in 1992 in his eighties. He was known as a Zionist but in the end he did not live in Israel after leaving Lebanon. He taught Ivrit with passion. 
Likewise the ancient $\star$ i is almost unanimously performed as $\check{z}$ and only sporadically do we find the allophone $\breve{g}$, especially in the root $\sqrt{ }<*$ جمع.

The original Ancient Arabic dental vibrant $r$ is rendered more by elderly informants, while the younger Jews shift it almost completely into its fricative voiced equivalent $\dot{g}$. Only in some original Hebrew words in the dialect are there deviations where the $r$ is kept. I assume that the shift to $\dot{g}$ did not occur in Israel but evinces a French influence on the pronunciation of this consonant.

The vowels produced by our informants lack almost entirely the use of the Lebanese Imāla. ${ }^{19}$ Rarely some informants (such as YP and YK) use certain words, for example, $\check{s} \bar{a} b b$ 'boy' with Imāla, although the plural form does not evince this feature: $\check{s} a b \bar{a} b$.

The dialect presents no diphthongs. There is a complete monophthongation of the Ancient Arabic *aw $(>\overline{0})$ and $* a y(>\bar{e})$. Only in place names, such as Bayrūt or Sayda, can one sporadically trace a diphthong, apparently in imitation of other Lebanese dialects, especially those of the Christians.

Nor is there any trace at all of pausal elongation, even though it is highly characteristic of the Syrian Macro dialectal group. This means that the second generation of Jews originally from Aleppo and Damascus did not use this type of speech. Pausal forms are absent, too.

\subsection{Morphology}

Morphologically the feminine ending is $-e$, not $-i$; the article is $e l-$, not $i l-$.

The verb in the I. Stem in perfect has the pattern $f^{\zeta} a l-$, e.g. $t r a k^{e} t$ ' ana [I left; SYN, 8] and in contrast to Palestinian dialects lacks a vowel, e.g. $\mathrm{fa}^{c} a l^{e} t$. Some verbs that in Classical Arabic normally have the pattern $f a^{c} a l$ appear in the texts in the form

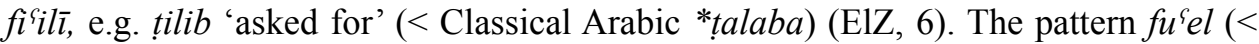
Classical Arabic *fa'ula) is attested, e.g. kuber 'grew up' (RL, 2).

In many of the above phonological and morphological features the dialect of the Jews of Beirut resembles Palestinian dialects, especially the dialect of the Jews of the Galilee region. ${ }^{20}$ Still, a morphological pattern typical of the Jews from Beirut is present, reflecting a similarity to Lebanese dialects. Examples are mišmoš 'apricot' instead of the Galilean mišmiš; Sižud 'a Jewish religious site in southern Lebanon' instead of Sužud; ${ }^{21}$ kitob 'books' (SyN, 5) instead of kutub as in the Jewish Galilean

${ }^{19}$ For more on Lebanese Imāla, see Levin (1972, vol. I, pp. 203-238). See also NaïmSanbar (1985, p. 218) who ascribes the use of the Imāla to the Christian population of Lebanon.

${ }^{20} \mathrm{I}$ began my work among Arabic-speaking Galilean Jewish informants some twenty years ago in the cities of Haifa, Tiberias, Safed, and Pqi în. Most of these Jews reached the Galilee after their expulsion from Spain in 1492. The majority came indirectly after living in northern Morocco, which explains the Maghrebi linguistic remnants in their speech. For more details, see the following two books and two papers: Geva-Kleinberger (2004 and 2009) and Geva-Kleinberger (2000 and 2005).

${ }^{21}$ This is a southern Lebanese holy site for Jews near the village of Rehān. The site is located on a mountain and is attributed to Oholiav Ben Ahi Samakh $\left[{ }^{H^{2}}\right.$ aholi? ${ }^{2}{ }^{v}$-Ben- ${ }^{2}$ Ahi-Samáx ${ }^{H}$, 
dialects. Also, Jewish Beiruti and Jewish Galilean dialects differ in the use of some personal pronouns. The former normally uses lihna ${ }^{22}$ 'we', the latter 'ihna; the Jews of Beirut also normally use hinnen ${ }^{23}$ 'they' while the Galilean Jews use hinne. The use of hunīk $\sim$ honīk $\sim$ hnīk 'there' is always Lebanese while in the Jewish Galilean dialects we find hunāk.

The demonstratives in singular, as attested in the interviews and in the texts, are normally hayda (m.) and haydi (f.) (MrZ, 1, 4), but the Palestinian (hence the Galilean) demonstratives are also attested, e.g. hädi (AA, 10).

Some informants use halli 'that' (YK, 5, 9) or even 'alli and yalli (Syn, 5), while others use 'illi which is regarded as more Palestinian. ${ }^{24}$

The informants normally use $m \bar{u} \sim m \bar{o}$ 'not' by negation of an attribute, although some informants speak the more Palestinian way of $m u s^{25}$

The genitive exponent is always $t a b a^{\varsigma^{26}}$ 'of', as in Galilean Jewish dialects.

One feature typical of the dialect of the Beiruti Jews is the omission of the final $-d$ in the numeral * wăhad, which turns into wăha $a^{27}$. It does not mean that wähad does not exist, yet we find wāha-rāyeh, wāha-žāy, wāha- ${ }^{\varsigma} a m-b i i^{\varsigma} a y y e t$ min hōn, wāha-bișarrex min hōn" 'He \{the High Commissioner\} saw one goes in, one goes out, one screams here, one shouts there'.

Most of the Jewish informants from Beirut display a very interesting feature which is also found in Galilean Jewish Arabic but cannot be traced in other Arabic dialects in the region. This is the use of Maghrebi remnants in numeral form, for example, the noun after the numeral is in singular and with a definite article, e.g. $x a$ -

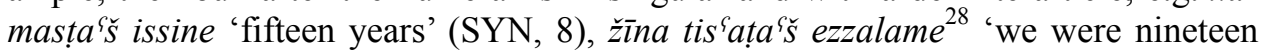
people who came'.

\subsection{Vocabulary}

The names spoken for the Jewish festivals resemble those spoken in the Galilean Jewish dialect, e.g. Sukkōt $\sim$ Sikkōt, Pēsah, Šavu'sot and so on. The expression 'rebbet

Heb. אהליאב בן אחי סמך], son of Ahisamakh of the tribe of Dan, and is described in Exodus 38:23. He worked under Bezalel as the deputy architect of the Tabernacle and the implements which it housed, including the Ark of the Covenant. The Jews made the ascent on donkeys before Lag ba${ }^{\varsigma} \overline{\mathrm{o}} \mathrm{mer}$. This was an occasion for the Beiruti Jews to meet Jews from Sidon and the Galilee region.

${ }^{22}$ See e.g. YP, 1-2. Compare 'ihna AA, 3.

${ }^{23}$ See e.g. YP, 4. See also Jiha (1964, p. 126): hinni, hin. Compare also Nakhla (1937, p. 56): henne.

${ }^{24}$ Cf. Behnstedt (1997, pp. 496-497, Karte 248). There are almost no data on Lebanon in this item, yet one can diagnose that halli is widespread in Syria's coastal region and in its other western parts.

${ }^{25}$ See e.g. YP, 5: here the informant uses muš by the negation of a verb in perfect: muš žìt 'I did not come'.

${ }^{26}$ See RL 4, 8, 10; YK 2, 5; AAA, 1; ElZ, 3,9. Cf. Behnstedt (1997, pp. 498-499, Karte 249).

${ }^{27}$ The Jews of Tiberias used wāh. See Geva-Kleinberger (2009, p. 58, e.g. sentence 12).

${ }^{28}$ Compare Feghali-Feghali (1978, p. 84, footnote 1). 
'the evening of a Jewish fast' is typical of the dialect under consideration. Some Jewish terminology also is the same in Beirut and in the Galilee region. Noteworthy is the use of the word kniss, which is feminine in the Beiruti Jews' dialect, e.g. elknis 'illi t'ammaret 'the synagogue which was built'; elknis elkbigge $e^{29}$ 'the Great Synagogue; Magen Avraham synagogue'. Sometimes this word has the feminine suffix - $t$ in annexations such as knīst eššwām [the Damascus Synagogue]. This pattern is also found in the Jewish dialect of Pqiīin in Upper Galilee.

The informants vary in their use of the word 'abi (SyN, 1, 2, 4, 5; YK, 4) bayyi (AAA, 2) 'abūy (AA, 2) 'my father'. 'abi is apparently not borrowed from Classical Arabic but naturalised in the use of some Beirut Jewish informants.

Some words may be regarded as typical of the Beiruti Jewish dialect, especially in plural forms. The word zalame 'man' has the plural zilim; sabt 'Saturday' has the plural sbüte.

There is also a wide range of words spoken in French in speech, but some of these have acquired an Arabic morphological form, e.g. ferüžz, which is a portmanteau word $<{ }^{*}$ Feu rouge 'traffic light'. The vowels that reflect French words imitate the French pronunciation, e.g. bi-lAli'eens ${ }^{F}$ 'in the Alliance (school)', while the French definite article in this word overlaps the Arabic $i l$ -

\section{Conclusions}

The Beirut Jewish dialect lacks some highly typical Lebanese features, such as the existence of Imāla and diphthongs, so it resembles more the Palestinian dialects than the Lebanese ones or even other dialects in the Greater Syrian Macro dialectal region. It is a coastal and urban Arabic dialect.

This dialect also differs in some features from that of the Jews of Sidon.

Some informants emphasised that the Lebanese capital Beirut had a medley of dialects (Bè $\bar{u}$ t lammāme ${ }^{31}$ ), each neighbourhood possessing its own dialectal features reflecting the city's different communities and religions; moreover, its Jews also came from different places and origins. Nevertheless, a unique Beirut Jewish dialect seems to exist that differs from other dialects there. Historically, the three legendary Jewish families that established the city's Jewish community apparently spoke a dialect influenced by their Sunnite neighbours: it, too, lacks certain prominent Christian dialectal features such as the Imāla and the absence of diphthongs. No remnants remained of a Druze dialect supposed to have existed in the Beirut Jews' dialect as many families came from Dèr el'Amar after 1860.

Ignoring the minute differences between Galilean Jewish Arabic dialects and the Beiruti Jewish dialect, these dialects resemble each other from many aspects.

${ }^{29}$ SyN, 2: wušš ilknīs likbig̀ge 'in front of the Great Synagogue'.

${ }^{30}$ Cf. Behnstedt (1997, pp. 520-521, Karte 260): bayyi is attested in northern Lebanon. The use of 'abüy in Syria is rare and is apparently a Palestinian influence. The feature 'abi is widespread in the eastern parts of Syria.

${ }^{31}$ Literally 'Beirut is collecting [in its nature]' = 'a complex mosaic'. 
Both have generally more Palestinian linguistic features and also Maghrebi remnants, although the Galilean Jewish dialects have more of these phenomena. Some of the Jewish families like the SYNs originally came from Pqi in in Upper Galilee before moving to Beirut. The geographical proximity to the Land of Israel made this community one of the closest to the Holy Land, and the Jews of Sidon even upheld the Jewish festivals as in Eretz Israel, namely they celebrated each of the three Pilgrimage festivals for only one day instead of two. ${ }^{32}$

Accordingly, I would suggest that the Beiruti Jewish dialect can be regarded historically as part of the Galilean Jewish dialects, although later the modern boundaries did not overlap the political borders. After the expulsion from Spain in 1492 some Jews apparently went to Lebanon after sojourning in the Jewish communities of the Galilee. There, in Tiberias, Safed, Pqi'īn, Shfar'ām, and Haifa, these Jews, who originally spoke Maghrebi Arabic dialects, were influenced by their Palestinian neighbours in the course of time. Gradually their Arabic dialect became more Palestinian than Maghrebi, albeit preserving some of the latter's linguistic phenomena. So I would suggest that the lack of typical Lebanese or Lebanese Christian features in the Jews' speech does not result from any influence of their Sunni neighbours on the development of their dialect, which also lacks some of those features, just as the Jews' speech contains no remnants from their 19th-century Druze neighbours either. In Beirut, some of the Galilean Jews found better financial opportunities. They had religious connections with rabbis and teachers from Safed, Tiberias, and Pqiīn. As a minority living mostly in the circumscribed area of Wādi $A b u$-Žminl, they continued to preserve their religious life and folklore. More importantly, they felt that they were still at the gates of the Holy Land.

\section{The Texts}

\section{A. SYN}

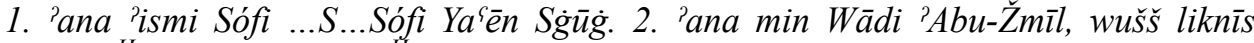
likbīge ${ }^{H}$ Magēn 'Avrahām ${ }^{H}$. 3. 'ana mžawwze kamān ma'a Libnāni. 4. hūwe kamān

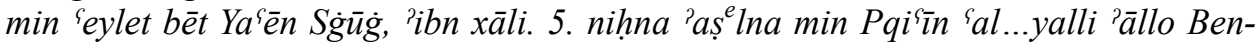

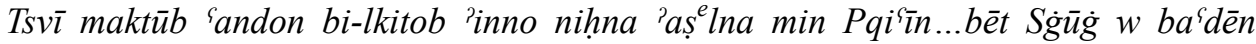

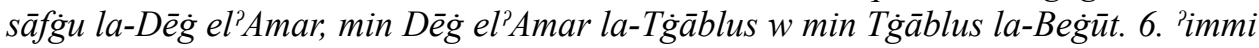

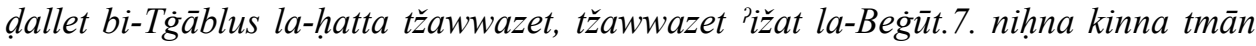

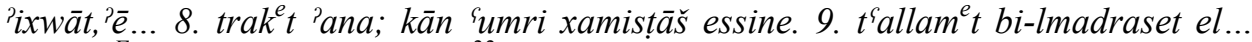

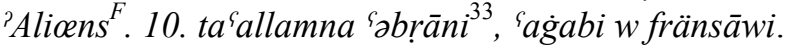

${ }^{32}$ Schulze (2001, p. 20): "The town of Said in the 1830s was surrounded by a little wall in which are very good streets and houses built of hewn stones, and the climate is wholesome. There are of native Israelites about 25 families, principally merchants; they have a small synagogue, they speak Arabic and have the same customs of Judea."

${ }^{33}$ Here with $r$ and not $\dot{g}$ as is usual. This might be the influence of the way of pronouncing Hebrew words based on the Torah reading. 


\section{Translation of A. SYN}

1. My name is Sofi...S. Sofi Ya'en Srur. 2. I am from Wadi Abu Jmeel, opposite the Great Synagogue, Magen Avraham. 3. I am married to a Lebanese too. ${ }^{34} 4$. He [her husband] is also from the Ya'en Srur family, being my maternal cousin. 5. Our origins are from Pqi ${ }^{i} \mathrm{i} n$... according to what Ben-Zvi ${ }^{35}$ said, that he has a written record that our origins are in Pqi'īn, that is, the Srur-family, which in the aftermath went to Der elAmar and from Der elAmar to Tripoli and from Tripoli to Beirut. 6. My mother lived in Tripoli until she got married and when she got married she went to Beirut. 7. We were eight sisters, yes. 8. When I left I was eighteen years old. 9. I studied in the Alliance $^{36}$ School. 10. I studied Hebrew, Arabic, and French.

\section{B. RL}

1. 'asāset 'èlet 'abi hiyye min Túrkya ${ }^{H}$. 2. 'abi xile? bi-Killes, w ba'd-ma ... bi-harb il... 'awlāni, tyattam min 'abu ve- ${ }^{H}$ min 'immo, $w$ 'axadū la-Halab w hun...hunīk

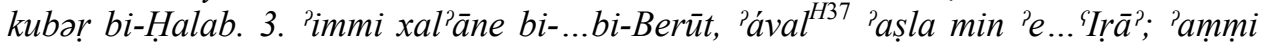
(sic) 'éelet Bag̀dādi. 4. 'abi ta'allam b...bi-bèt yítama bi-Halab ma l...bi-matrah taba lyahūd w kabbarūlo... kabar ma'a 'arba'-xams 'axwāto. 5. ba'ad-ma kān 'e ...fi tarīi la-Berūt - 'iža yiskon bi-Berūt $w$ hun...hunēk...hunāka ta'arraf 'ala 'abi (sic)...'abi ta'arraf 'ala 'immi w tžawwazu w žābu sab'a 'awlād-wāhad 'a $\bar{a}^{\varsigma}$ ed biFrānsa lyōm,

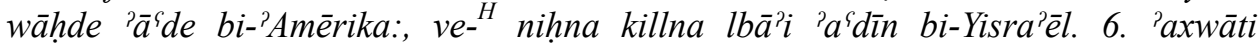
sākn...wāhad (sic) min 'axwāti șākne bi-Goš-ha- ${ }^{\complement} \bar{A} y i n, w$ ttānye sākne bi-Bnēy Brāāk,

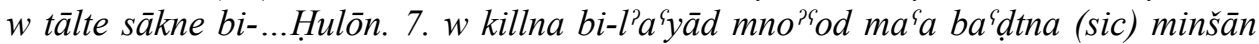

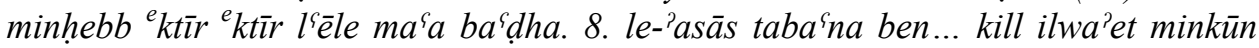

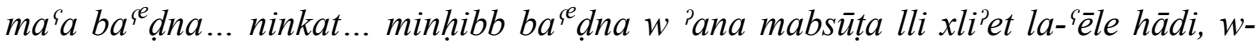
nšaLLa bi-sint el...žāyye minsāfer killna-killna la-`ind 'axi bi-Frānsa minšān hāābbîn minkūn ma'a ba`aḍna. 9. 'ana ktīr mabsūța 'alli e... fi hayāti (m)tžawwze ma`a wā...rižžāl Romani ${ }^{H}$...bass bihki kamān šwayye 'arabi, minšān kill wa'et lamma

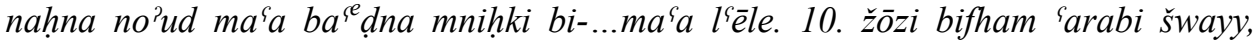

${ }^{34}$ Meaning Lebanese Jew.

${ }^{35}$ Yitzhak Ben-Zvi (Hebrew: צחק בן צבי; 24 November 1884-23 April 1963) was a famous historian of the Jews of the Galilee and the second and longest-serving President of Israel.

${ }^{36}$ Kirsten E. Schulze (2001, p. 25): "Lebanese Jews after their interlude in Mount Lebanon became an urban population who were Arabic-speaking and French educated. In that sense, they lagged behind other Middle Eastern Jews who tended to have ceased to be an agricultural people during the seventh and eighth centuries, but unlike other ancient populations, returned to life as a nation of merchants and artisans. They have been described as assimilated into the Arab population save in greater Westernization of mind and habit. They managed their own community within the millet system with their own schools as well as those of the Alliance Israélite Universelle. In addition to the schools of the Alliance, missionary schools started to attract more Jewish students from the mid-nineteenth century onwards."

${ }^{37}$ This word apparently entered as a result of the life in Israel and the influence of Ivrit. 
wlädi mu-ktīr, bass 'ana be...bahassev ${ }^{H}$ 'inni be... 'inna...m...mist'idde 'inno 'awlādi kamān ya'rfu 'arabi, minšān bahassib 'inno hiyye lsān mnīha ya'rfu kill iliwlād biYisra'ēl ta-y ifhamu l'adu taba'on.

\section{Translation of B. RL}

1. The origin of my father's family is Turkey. 2. My father was born in Killes ${ }^{38}$ and after the...World War I, he lost his father and also his mother and he was taken to Aleppo and from...there...he grew up in Aleppo. 3. My mother was born in...Beirut, but her origins are in...Iraq; my mother is originally from the Baghdadi-family. 4. My father studied in an orphanage in Aleppo, in a Jewish place and he grew up...he grew up together with his four-five brothers and sisters. 5. After he was...on his way to Beirut, he came to live in Beirut, and...there...there... he met...my father...my father met my mother and she married him and they had seven children: one lives today in France, the second daughter lives in the United States, and all the rest of us live in Israel. 6. My sisters live... one of my sisters lives in Rosh ha- ${ }^{5}$ Ayin, another one in Bney-Brak and the third one in Holon. 7. We celebrate, all of us, the [Jewish] festivals, because we love very much that the family is all together. 8. Actually...we are all the time together...we love each other and I am happy that I was born to this family, and hopefully next year, we will go, all of us, to visit my brother in France, because we would like to be together. 9. I am very happy that...I married a Romanian man who...also speaks Arabic a bit, since all of us when we are together we generally speak Arabic in...the family. 10. My husband understands Arabic a little bit, but my children not so much, yet I think... I would like my children to understand Arabic too, since I think it is a nice language that all children in Israel should know, in order to understand their enemy.

\section{YP}

1. kānet hayāt hilwe ktīr... w lihna nbasatna. 2. w kān fì 'axawiyye, lihna w žiranna,

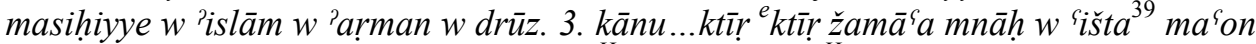
il'amar killo. 4. wa'et illi biddi 'aži la- ${ }^{{ }^{H}}{ }^{\top} \dot{E}$ rets Yisra'è ${ }^{3}$ - hinnen sa'adūni $w$ 'irfu $w$

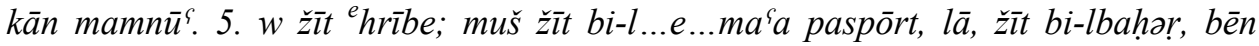

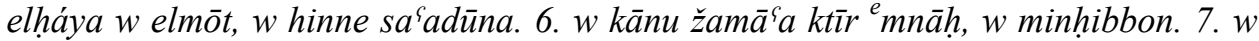
elyahūd killon kānu mabsūtīn ${ }^{e} k t \bar{t} r$, $w$ 'ažg̀àlon $w$ ttužăra wilkill. 8. w kānu byūtna mnāh. 9. $w$ elyahūd ${ }^{e}$ hnīk māa-yit ătu ma ${ }^{\varsigma} \bar{a}$ hada, žiriton hilwe $w$ mā bitdaxxalu dvarīm ${ }^{H}$ 'illi mā bitxușșon. 10. minšān hēk 'ista'darūna ktīir w'a 'addarūna.

${ }^{38}$ Kilis (Turkish), Kilîs (Kurdish), is a city in south-central Turkey, near the border with Syria. This city had about 300 Jewish families at the end of the 19th century.

${ }^{39}$ Apparently a Classical Arabic influence. 


\section{Translation of C. YP}

1. It was a very beautiful life, and we enjoyed it. 2. There was brotherhood between us and our neighbours, Christians, Moslems, Armenians, and Druze. 3. They were very good people and we lived with them all our life. 4 . When I planned to come to Israel they helped me, although they knew that it was forbidden. 5. I came illegally, without a passport, no, I came by sea, between life and death and they helped us. 6 . They were very nice people and we loved them. 7. All the Jews were very content: their jobs, their trade and everything. 8. Also our houses were very nice. 9 . The Jews there do not interfere with anybody, their neighbourly relations are nice and they don't stick their noses into things that are not their concern. 10. That is the reason that they [her neighbours] appreciated us a lot and respected us.

\section{YK}

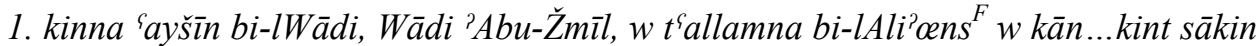
bi-Zarūbat elMenn, Zag்ūbat ${ }^{40}$ elMenn. 2. w halli batzakkarha min tufúlti...min

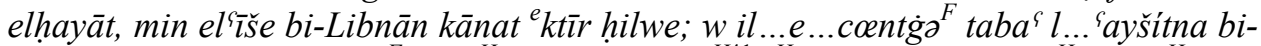
Beygūü kānet e lAli'oens ${ }^{F}$, el ${ }^{H}$ Magén Dav... ${ }^{H 41}{ }^{H}$ Magén 'Avrahám ${ }^{H}$ w el ${ }^{H}$ batémidrás ${ }^{H}$ halli min dāyer elknīs. 3. 'ana kint esalli bi- ${ }^{H}$ Bet-Midráśs elMenn, 'Izāk ...Yitshạa $k^{H}$ lMenn, kan-huwwe māsek el ${ }^{H}$ Bet-Midráśs ${ }^{H}$-bi-Zag̀ūbet elMenn. 4. w kint hunīk 'aṣalli ma ${ }^{\varsigma} a{ }^{2} a b i$, kill sabet $w$ 'a $a^{\varsigma} y \bar{a} d$. 5. $w$ halli batzakkag min ${ }^{H}$ Magén

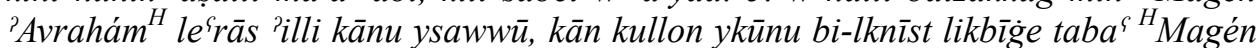

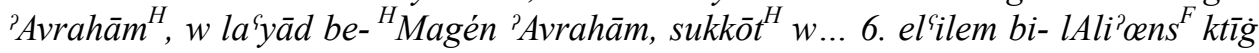

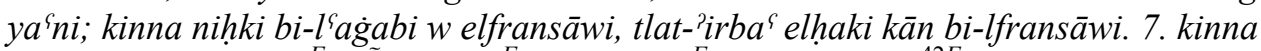

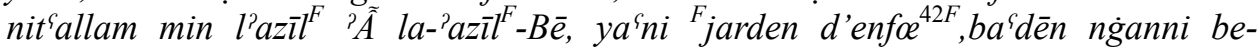

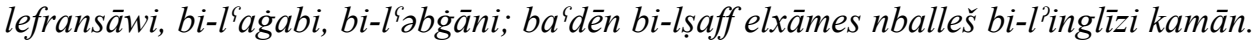

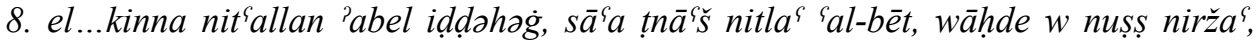

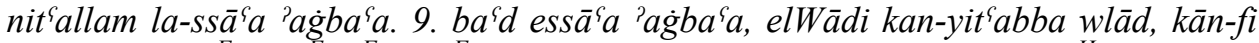

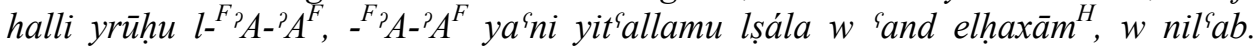

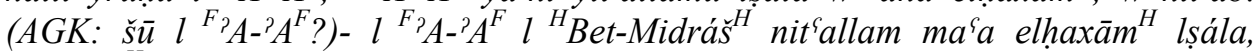

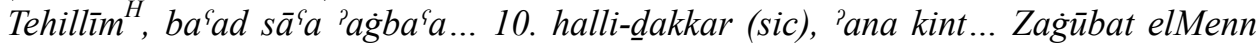

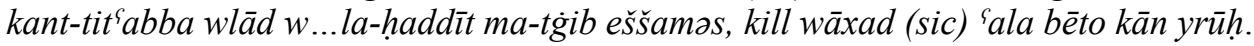

\section{Translation of D. YK}

1. We lived in the Wadi, Wadi Abu-Žmìl, and we studied at the Alliance-School....and I lived in elMenn ${ }^{43}$-Alley, elMenn-Alley. 2. What I remember from my childhood is...from my life...the life in Lebanon, is that it was very beautiful; the centre of our

${ }^{40}$ Arabic زروبة. See Barthélemy(1935, p. 309): 'zarūb pl. zwerīb ruelle longue et étroite'.

${ }^{41}$ The intention seems to be 'Magén David' 'Star of David'.

${ }^{42}$ Jardin d'enfants.

${ }^{43}$ After the name of Itzhak elMann, a wealthy Beiruti Jew. See also Levi (2012, p. 174). 
life in Beirut was the Alliance and Magen Dav...Magen Avraham and the several Batey-Midrash around the synagogue. 3. I prayed in Bit-Midrash elMenn, [named for] Isaac, Itshak elMenn and the Bet-Midrash was in elMenn-Alley. 4. I prayed there with my father every Saturday and on the [Jewish] festivals. 5. What I still remember from the Magen Avraham [synagogue] are the weddings that took place there, since all of them took place in the Great Synagogue of Magen Avraham, and also [he recalls] the festivals at Magen Avraham such as Sukkot. 6. In the Alliance there was lots of study; we spoke in Arabic and French as three-quarters of our speech was in French. 7. We learned from Class- $A$ to Class- $B$ in the kindergarten, I mean Jardin d'enfants and then we used to sing in French, Arabic and Hebrew; afterwards in the fifth class we began to learn English as well. 8. We studied before noon, and at twelve o'clock we went home and at one thirty we went back and studied until four o'clock. 9. After four o'clock the Wadi gradually filled up with children, since some of them went to the $A . A$., it means they went to learn to pray, to go to the Rabbi and then we went to play. ( $\mathrm{AGK}^{44}$ : What does A.A. mean?) A.A. is the Bet-Midrash where we learned with the Rabbi to pray and to [learn] Psalms; and then after four o'clock... 10. What I remember is that the Menn-Alley would fill up with children until... the sun set, and then everyone went to his own home.

\section{E. AA}

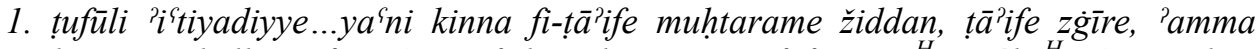

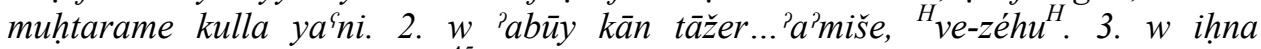

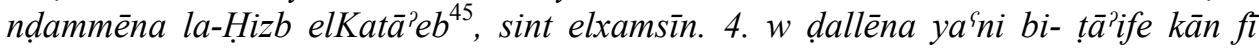
'inna 'asātze lli kānu ymaššūna 'a-ț̣arī'a 'illi kān biddon iyyāha ya'ni. 5. w kānt hayāt hilwe ya'ni, mā kānš nā'eșna walla-'iši ya'ni. 6. w ilyahūd 'illi nzalamu bidduwal l'arabiyye... 'ị̣na mā kān...kull 'iši tamām! mā hadan 'ažu 'alēna ya'ni. 7. 'alīl șārat hạawālay sane, 'ifradiyye ya'ni, li-lli yī̌u nnās yitharrašu yinzalu 'ala

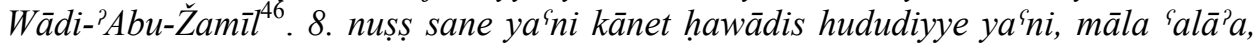
'amma ššs $a^{\varsigma} b$ kān yhibbna ya'ni w ma-kanneš, mā-kan ya'míkna 'iši ya'ni; la-'inn lKatā'ib kullna mundammīn la- Hizb elKatā'eb, w Hizb elKatā'eb kān ydāfe elyahūd ktīr. 9. 'a-’iyyām Pyēr ižŽmayyel, 'All la yírhamo. 10. w hädi hiyye... hādi hiyye lhayāt; $w$ ba d sant issab ${ }^{\varsigma} a w$ sittīn, ba $a^{\varsigma} d$ harb l'iyyām issitte, bada'ü lyahūd yițla'u min Lubnān.

${ }^{44}$ Aharon Geva-Kleinberger.

${ }^{45}$ The Lebanese Phalanges Party (Arabic: حزب الكتائب اللبنانية Hizb al-Katā'ib al-Lubnānìya); a Christian right-wing political party in Lebanon. According to my informants, many Jews of Beirut were members of this party and even in its scout movement. The Phalanges Party guarded the Jewish neighbourhood during the Six Day War from penetration of demonstrations.

${ }^{46}$ Normally called by the Jews $W \bar{a} d i$ - $^{2} \mathrm{Abu}$-Žminl, the Jewish neighbourhood in the centre of Beirut. Formally known as Wādi elYahūd 'Valley of the Jews'. At its centre was the Magen Avraham synagogue which was built by the Sassoon family of Bombay. 


\section{Translation of E. AA}

1. My childhood was a normal one... I mean, we were in a most respected community, albeit a small one, but very distinguished. 2. My father was a merchant in fabrics...and that's all. 3. We [= I] joined the Kataeb Party in 1950. 4. We [= I] resumed my life in the community and we had leaders that led us in the way they thought suited us. 5. It was a beautiful life and lacked for nothing. 5. As for the Jews that were abused in Arab countries...we had nothing at all of that sort! Nobody attacked us. 7. It happened only rarely, for example, during approximately one year, but these were only single cases, when some people came to Wadi Abu-Žamīl in order to stir up trouble. 8. For half of a year there were some troubles on the borders [between Lebanon and Israel] which had nothing to do with us; the people loved us and did us no harm, since we were all members of the Kataeb Party and the Kataeb Party protected the Jews a lot. 9. [Especially] during the time of Pierre Jumayyil, of blessed memory. 10. And that was... that was the life; after 1967, after the Six Day War, the Jews began to emigrate from Lebanon.

\section{F. AAA}

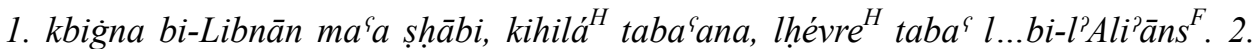

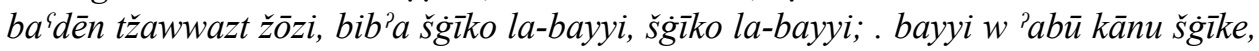

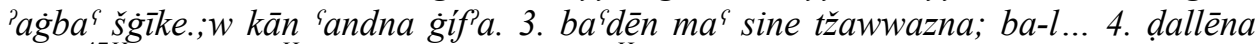
kámo ${ }^{47 H}$ famílya, ${ }^{H}$ mišspaháa' $w$ be-sēdeg ${ }^{H}$, hamdi-LLāa. (AGK: $w$ haflet il'iris wēn kānat?)- bi-liknīs ${ }^{H}$ Magén- ${ }^{2} A$ brahám $^{H}$. (AGK: ya'ni dā'iman kānu yi ${ }^{\zeta}$ malu hunīk?)-

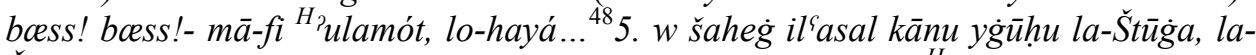

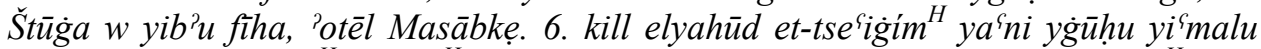

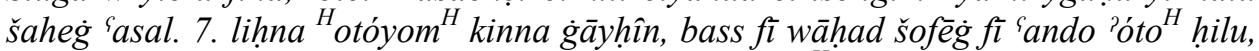
ya'milna lyahūd, huwwe yahūdi, Dōdž, kān 'indo 'óto ${ }^{H}$ hilu, 'âxidna šaheg 'asal. 8. wa? afüna hunīke 'a-l'ḥdüd, 'inno maktūb 'ala-lhawiyye 'inno 'Isra'iliyye. 9. walla

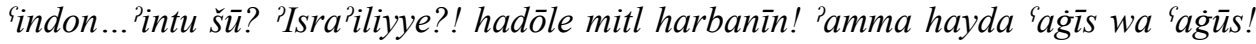
10. taha? $a^{\text {? }} a^{?} u$ ma ana $w$ talla'u 'inno maz̧būt lihna Lubnaniyye bass maktūb elmawalìd...elžinsiyye 'Isra'iliyye, bass lihnna yahūd! - ${ }^{2} a{ }^{H}$ ba atūna ...

\section{Translation of F. AAA}

1. We $[=\mathrm{I}]$ grew up in Lebanon with my friends and with our [Jewish] community and with our guys from the Alliance. 2. Afterwards I married my husband who was my father's partner, my father's partner; my father and his father were partners [in a company], four partners; and we also had friends. 3. After one year I married. ... 4. We remained like a family, [one big] family and everything was fine, thank God.

\footnotetext{
כמו > 47

${ }^{48}$ There is a break in the recording.
} 
(AGK: And where was the marriage?) In Magen Avraham Synagogue. (AGK: All the marriages were there?) Just there! Just there! There were no marriage halls. 5. There was a tradition to go to Shtura ${ }^{49}$ for the honeymoon, to go to Shtura and stay at the Hotel Masabke. 6. All the young Jews used to go there for honeymoon. 7. On that day, as we were going, there was one driver who had a nice car, he would take us Jews, since he was also a Jew; he had a Dodge, a nice car and he took us to the honeymoon. 8. We were stopped there at the border, since it was written on our identity cards that we were Israelis. ${ }^{50} 9$. They were surprised to have...'What are you? Israelis?!' - 'It looks as if they're running away!' But 'This is a groom and a bride! ${ }^{, 51}$ 10. They questioned us and found out that we were Lebanese, although it was written that we were born... our identity was 'Israeli', but we were Jews! Finally we were released...

\section{G. EIZ}

1. kān e... 'iyyām il'intidāb lamma ...lamma lFransawiyye kānu bi-...bi-Bayrūt, kān-fi $\varsigma^{\varsigma} \bar{d}$ de 'inno bi-l'a'yād yiži l...lmandūn elFransāwi la-lknīs ${ }^{H}$ Magén 'Avrahám ${ }^{H}$ lahatta y'ayyed elțāyfe. 2. kān kull ra'īs ilțāyfe w elhaxamīm ${ }^{H}$. 3. marra min elmarrāt, bažnni yimken Pēsah ${ }^{H}$ 'aw Sukkōt ${ }^{H}$, 'iža lmandūb elFransāwi $w$ 'amlūlo haflet

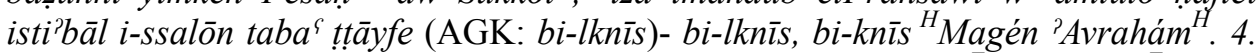

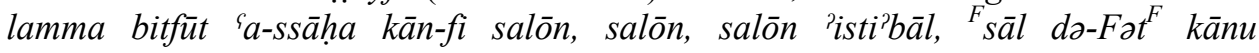

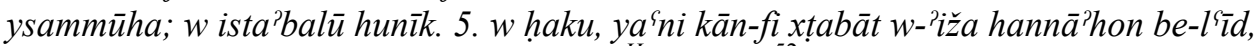

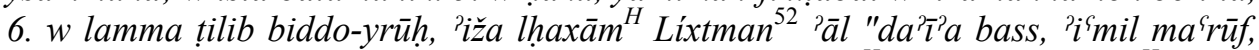
biddi-faržīk ši". 7. "lha'ni!" 8. 'axadon. 9. wara knīs ${ }^{H}$ Magén 'Avrahám ${ }^{H}$ kān-fi Imadrase, ${ }^{H}$ Talmúd Torá ${ }^{H}$ taba $a^{\varsigma}$ Salīm Tarrāb. 10. btițla bi-ssillom, bi-noṣs issillom

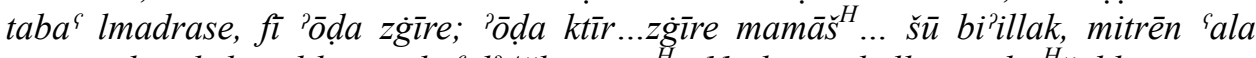

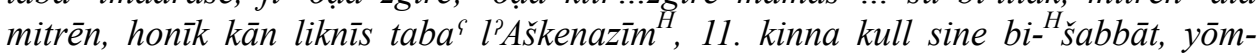
ši... ${ }^{53 H}$, yom-el... yom-ežžim'a (AGK: šū kān 'ismo?) - mā...māa-kan ...Knīs isSkānze,

${ }^{49}$ Shtura or Chtaura is a town in Lebanon in the Beq $\bar{a}^{\varsigma}$ valley, less than 50 kilometres from Beirut.

${ }^{50}$ In Lebanese identity cards and passports the word for Jews was 'Isrā'îliyyi 'Israelite', not Yahüdi or Musawiyy as in Syria.

${ }_{51}^{51}$ Apparently the words of the driver.

${ }^{52}$ Chief Rabbi Benzion Lichtmann. See Schulze (2001, p. 104): “At the end of 1959, Chief Rabbi Ben Zion Lichtman [sic!] also left Lebanon. It was a sad day for the community. Rabbi Lichtman, who had been born in Brailov (Lithuania) into a Hassidic family, had moved to Beirut in 1932. Before moving to Beirut he had lived in Jerusalem and Tel Aviv. He had immigrated to Palestine in 1923/4 from Russia where he had been a young militant, active in the ultra-religious Agudat bYisrael, and had devoted much of his free time to researching rabbinic literature, with a specific interest in the Shulchan Aruch. He had not wanted to leave Palestine, but the economic situation was very bad, and he needed to find a way to support his family. From a relative that travelled in the region he heard that the Beirut community was looking for a shochet. So he went. After his arrival in Beirut, he went to the main synagogue on Erev Shabat. He was immediately spotted as a 'foreigner' and invited for kiddush."

53 yōm-šiši 'Friday'. 
Knīs išškānze. 12. $w$ kinna nrūh hunīk kull sine bi-... yom-ežžim'a ’illi taba Hánuka ${ }^{H}$, minșalli ${ }^{H}$ Minháa Gdolá ${ }^{\dot{H}}$ hunīk ta-mnșīr mnša ${ }^{\varsigma \varsigma}$ el hanuká ${ }^{H}$ bi-lbēt ba'dēn. 13. ba'a...rihnna, 'áxadon lhaxām ${ }^{H}$ Lìxtman la-lmandūb elFransāwi, țil'u ta-yzūru hunīk. 14. daxal, 'allon 'wē̄n knīs el'Aškenazim ${ }^{H}$ ?' ma-ta'rif 'ind el'Aškenazim ${ }^{H}$ mū mitl 'ind esSefaradim ${ }^{H}$; Sefaradim ${ }^{H}$ bye ${ }^{\uparrow \varsigma}$ adu kull wāhed b-mahallo, kull wāhid $b$ makāno, byișallu, w elhazāon ${ }^{H}$ huwwe 'illi bidīr elminhā̄̌. 15. bi-lKnīs išŠkānze tịli

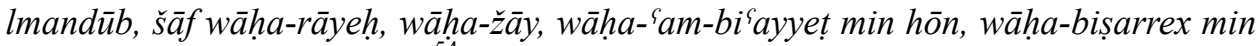
hōn, w kull wāhad b-häyda. ${ }^{54}$ 16. šăf; 'allo 'hōn Knīs isSkānze bi-Bayrūt, w' 'ana

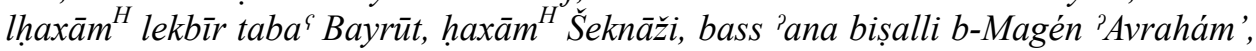
hēk 'allon, minšān etțāyfe honīk. 17. hinne w nazlīn, dār lmandūb lFransāwi, ba'a haxāa ${ }^{H}$ Lìxtman mā-kan yihki fransāwi; židdi haxām ${ }^{H}{ }^{2} E l y a \bar{a} h u$ kān yihki fransāwi w ra'īs etțāyfe 'Ațiyye kān yihki fransāwi; dār la-'andon $w$ 'allon ... bi-lfransāwi willa bi-l'arabi? (AGK: 'iza thaddas bi-lfransāwi fal-ykūn bi-lfransāwi!) - $w$ 'allon bilfransāwi 'F métno že kompro ke purkwa le žwīf so ontzližz ${ }^{55 \text { 'F }}$; 'alūlo 'purkwa ${ }^{56 F}$ ?' 'allo 'minšān hattu Filz-on-mi la-fū sal...non normál so... ${ }^{57 F}$, [laughs] - hatțu lmažanin la-halhon! hāy 'oṣșa!

\section{Translation of G. EIZ}

1. At the time of the Mandate, when the French were in...in Beirut, there was a custom during the [Jewish] festivals that the French High Commissioner came to Magen Avraham Synagogue to celebrate with the community. 2. The community's head and the rabbis were there. 3. Once, I assume during Passover or Sukkot, the High Commissioner came and they held a reception party for him in the community hall. 4. When you entered the yard, there was a hall, a hall, the community hall; it was called Salle de fêtes, and they held the reception for him there. (AGK: Was it in the synagogue?) [Yes], in the synagogue, at Magen Avraham Synagogue. 5. They talked, I mean there were speeches, and he came to greet them for the festival. 6 . When he asked for permission to leave, Rabbi Lichtmann came and said: 'Just a moment, do me a favour, I would like to show you something'. 7. 'Please follow me!' 8. He took them. ${ }^{58}$ 9. Behind the Magen Avraham Synagogue there was a school, the Salim Tarrab Talmud Torah. ${ }^{59} 10$. You had to climb a ladder [to reach it]; half way up the ladder leading to this school there was a little room, a really tiny room - what can I tell you? Two metres by two metres; there was the Ashkenazi Synagogue. 11. We

\footnotetext{
${ }_{55}^{54}$ Here long and not hayda as normally.

${ }_{56}^{55}$ Maintenant, je comprends pourquoi les Juifs sont intelligents.

${ }^{56}$ Pourquoi.

${ }^{57}$ Ils ont mis les fous seuls. Non normal sont [= Ils ne sont pas normaux].

${ }_{58}^{58}$ Apparently, the High Commissioner arrived with a delegation.

${ }^{59}$ Schulze (2001, p. 43): "The Ecole Talmud Torah Selim Tarrab was located within the premises of Magen Avraham. Both the school and the synagogue provided the community as a whole with an impressive neighbourhood as well as functioning as a vehicle for the community leadership to counter de-Judaization and religious indifference." For more on the structure of Talmud Torah in Beirut, see Levi (2010, pp. 197-198).
} 
used every year on Saturday, on Friday to... (AGK: What was its name?) It did not have... it did not have a name, it was just called 'the Ashkenazi Synagogue'. 12. We would go there every year, on the Friday of Hanukah to say the Minha Gdola ${ }^{60}$ prayer there, and afterwards would light the Hanukiyah at home. 13. So Rabbi Lichtmann took the French High Commissioner to visit there. 14. He entered and asked them, 'Where is the Ashkenazi Synagogue?' As you know, the Ashkenazim are not like the Sephardim; every one of the Sephardim sits down in his place, in his own seat and prays, and the Cantor leads the service. 15. In the Ashkenazi Synagogue the High Commissioner saw someone going in, someone going out, someone yelling here, someone shouting there - and everything was chaotic. 16. He was staring; he said to him: 'Here is the Ashkenazi Synagogue of Beirut, and I am the Chief Rabbi of the Ashkenazi community of Beirut, but I pray in Magen Avraham Synagogue for that [Ashkenazi] community. 17. Going down, the French High Commissioner turned, as Rabbi Lichtmann did not speak French, while my grandfather Rabbi Eliyahu spoke French and so did Rabbi Atiyya, the head of the community - he turned to them and said to them... Shall I tell it to you in French or in Arabic? (AGK: If he was talking in French, please quote it in French). He said to him in French: 'Now I understand why the Jews are so intelligent!' They asked him [in French]: 'Why then?' He answered: 'Because they put, they put the crazy people separately, since they are not normal!' [he laughs]. They had put the crazy people separately! What a story!

\section{H. MrZ}

1. ya'ni haydi fadīha haydi! 2. 'iza bna-niḥki 'ala binit masalan, biddi 'aharkíša: "rūḥ

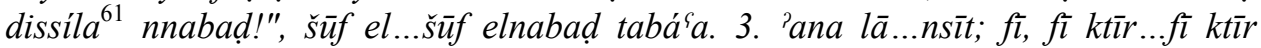
e...masa...mašă $\bar{a}^{\varsigma}$...masā̄el min ha-nnō'. 4. masalan "hāy ilbinit haydi btistāhel

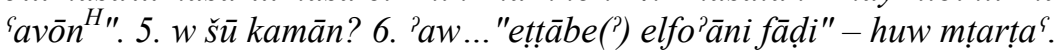

\section{Translation of $\mathbf{H}$. MrZ}

1. This is a real scandal! $!^{62} 2$. If we wanted to speak about a certain girl and I wanted to tease her, [they used to say in the Jewish community of Beirut]: 'Go and check her pulse! Go and look at her pulse! ${ }^{63} 3$. I cannot... I have forgotten; there are many expressions...many things like that. 4. For example: 'This girl deserves ${ }^{\varsigma} a v \bar{o} n^{H} .{ }^{64} 5$. And what else? 6. And also... 'His upper storey is empty', meaning 'he is stupid'.

${ }^{60}$ Etymologically, the term Minha means 'a present'; it denotes the meal offering that accompanied each sacrifice offered in the Jewish Temple. The Minha service may be recited from half an hour after halachic noontime. This earliest time is referred to as Minha gedola 'Large Minha'. It is, however, preferably recited after mincha ketana 'Little Minha'.

جس النبض >

${ }^{62}$ The informant was asked to speak in Arabic after a long interview in Hebrew.

${ }^{63}$ Euphemism; denotes a sexual allusion.

${ }^{64} \mathrm{~A}$ sin, according to Judaism. 


\section{MsZ}

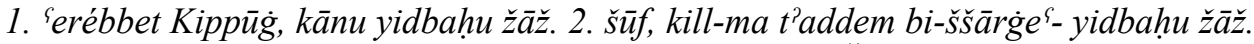

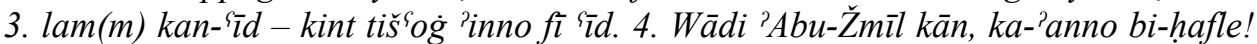
${ }^{. .}{ }^{65} 5$. 'ag̀labiyyet essukkót ${ }^{H}$ kānu bi-lkanāyes. 6. liknīst-likbìge masalan kān 'andak

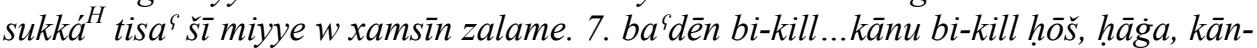
fi kam sukká ${ }^{H}$, 'iza lwāhed saw(w)a sukká ${ }^{H}$ - killon bifūtu. 8. 'issa, 'ağlabiyyat

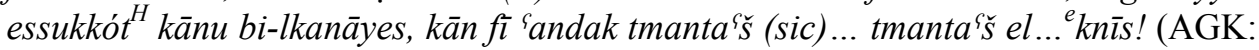
zākir kill 'asamīhon?) - 'ağlabiyya 'aftikir. 9. kān-fi 'andak elHalabiyye. 10. 'awwalan kān-fi 'andak taba' tawāli, fi-'andak elHalabiyye; fi-'andak elSpanyoliyye,

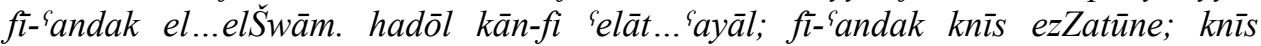

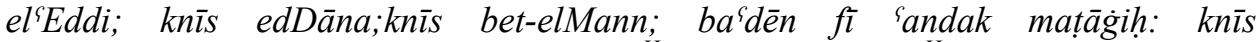

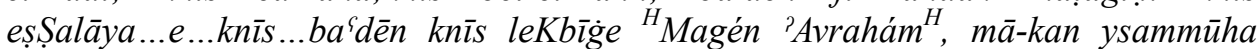
${ }^{H}$ Magén 'Avrahám ${ }^{H}$, kān ysammūha Knīs liKbìge, w 'eddām knīs... 'eddām Knīs

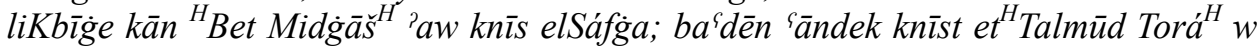
knīs el'Ali'cens.

\section{Translation of I. MsZ}

1. In Yom Kippur eve they would slaughter chicken. 2. Look: as you were going along the street you could encounter people slaughtering chickens. 3. When there was a [Jewish] festival you could feel its atmosphere. 4. Wadi Abu-Jmil looked like a whole celebration!... 5. Most of the sukkot were in the synagogues. 6. In the Great Synagogue there was for example a sukkah which held one hundred and fifty people. 7. Additionally, in each...in each yard, in each sub-neighbourhood there were several sukkot and if somebody built a sukkah everybody could enter. 8. Now, most of the sukkot were in the synagogues: there were eighteen...eighteen synagogues! (AGK: Do you remember all their names?) I think that I recall most of them. 9. There was the Aleppine Synagogue. 10. There were synagogues in the following order: the Aleppine; the Andalusian; the Damascene; Zatūne Synagogue; Eddi Synagogue; Dana Synagogue; Mann Synagogue. And then you had places like the Șalayya and then there was the Great Synagogue which was not actually called by its name Magen Avraham but [rather as] the Great Synagogue, and facing...the Great Synagogue was the Bet Midrash of Safra ${ }^{66}$ or [as it was known] Safra Synagogue; next come the synagogue of Talmud Torah and the synagogue of Alliance.

${ }^{65}$ A pause in the recording.

${ }^{66}$ Levi (2010, p. 50): "In 1920, Jacob Safra, a member of an Aleppo banking family, migrated to Beirut and founded a bank...The family lived in Beirut and was part of its Jewish community for three decades until its members migrated to Brazil in 1952." 


\section{Bibliography}

Abu-Haidar, Farida (1979): A Study of the Spoken Arabic of Baskinta. Leiden-London, E. J. Brill.

Barthélemy, A. (1935): Dictionnaire Arabe Français: Dialectes de Syrie: Alep, Damas, Liban, Jérusalem. Paris, Librairie Orientaliste Paul Geuthner.

Behnstedt, Peter (1997): Sprachatlas von Syrien. Wiesbaden, Harrassowitz Verlag.

Feghali, Michel-Feghali Joseph (1978): Contes, Légendes et Coutumes Populaires du Liban. Louvain, Université Catholique de Louvain, Institut Orientaliste Louvain-la-Neuve.

Geva Kleinberger, Aharon (2000): Living amongst the Spirits: Death and Superstition as Reflected in the Arabic and Hebrew Vocabulary of the Jews of Safed. Mediterranean Language Review (MLR) Vol. 12, pp. 18-40.

Geva Kleinberger, Aharon (2004): Die arabischen Stadtdialekte von Haifa in der ersten Hälfte des zwanzigsten Jahrhunderts. Wiesbaden, Harrassowitz Verlag (Semitica Viva 29).

Geva Kleinberger, Aharon (2005): Last Informants of the Jewish-Arabic Dialect of the Ancient Community of Peqi'in. WZKM Vol. 95, pp. 45-61.

Geva Kleinberger, Aharon (2009): Autochthonous Texts in the Arabic Dialect of the Jews of Tiberias. Wiesbaden, Harrassowitz Verlag (Semitica Viva 46).

Jiha, Michel (1964): Der arabische Dialekt von Bišmizzīn. Wiesbaden-Beirut, In Kommision bei Franz Steiner Verlag (mit Unterstützung des Deutschen Akademischen Austauschdienstes und der Botschaft der Bundesrepublik Deutschland im Lebanon in der Imprimeries Catholique, Beirut).

Levi, Tomer (2010): The Formation of a Levantine Community: The Jews of Beirut 1860-1939. Brandeis University, a dissertation in the Department of Near Eastern and Judaic Studies.

Levi, Tomer (2012): The Jews of Beirut: The Rise of a Levantine Community 1860s-1930s. New York, Peter Lang.

Levin, Aryeh (1972): ha-Imāla ba-Dialéktim ha- ${ }^{\varsigma}$ Arviyím (in Hebrew = The 'Imāla in the Arabic Dialects). PhD Dissertation. Jerusalem, The Hebrew University.

Naïm-Sanbar, Samia (1985): Le Parler Arabe de Rās-Beyrouth (Liban). Paris, Geuthner.

Nakhla, P. Raphäl (1937): Grammaire du Dialecte Libano-Syrien (Phonétique, Morphologie et Syntaxe). Beyrouth, Impimerie Catholique.

Qabbāni, Shīrīn (2014):Yahūd Lubnān yaksirūna 'Uzlatahumu țṬawīla bi-'T'āda Fatḥ Kanīs Māgēen ${ }^{2}$ Abrāhām [in Arabic $=$ The Jews of Lebanon break their long silence after the reopening of the Magen Avraham synagogue]. ash-Sharq al-' Awsat (newspaper) 16/05/2014.

Schulze, E. Kirsten (2001): The Jews of Lebanon, between Coexistence and Conflict. Brighton, Portland, Sussex Academic Press. 